\title{
Effects of Chinese herbal medicine on plasma glucose, protein and energy metabolism in sheep
}

\author{
Xi Liang, Kyota Yamazaki, Mohammad Kamruzzaman, Xue Bi, Arvinda Panthee and Hiroaki Sano*
}

\begin{abstract}
Background: The use of antibiotics in animal diets is facing negative feedback due to the hidden danger of drug residues to human health. Traditional Chinese herbal medicine has been used to replace antibiotics in the past two decades and played an increasingly important role in livestock production. The present study was carried out to assess the feeding effects of a traditional nourishing Chinese herbal medicine mixture on kinetics of plasma glucose, protein and energy metabolism in sheep. Ruminal fermentation characteristics were also determined.
\end{abstract}

Methods: Four sheep were fed on either mixed hay (MH-diet) or MH-diet supplemented with $2 \%$ of Chinese herbal medicine (mixture of Astragalus root, Angelica root and Atractylodes rhizome; CHM-diet) over two 35-day periods using a crossover design. The turnover rate of plasma glucose was measured with an isotope dilution method using $\left[\mathrm{U}-{ }^{13} \mathrm{C}\right] \mathrm{glucose}$. The rates of plasma leucine turnover and leucine oxidation, whole body protein synthesis (WBPS) and metabolic heat production were measured using the $\left[1-{ }^{13} \mathrm{C}\right]$ leucine dilution and open circuit calorimetry.

Results: Body weight gain of sheep was higher $(P=0.03)$ for $\mathrm{CHM}$-diet than for $\mathrm{MH}$-diet. Rumen $\mathrm{pH}$ was lower $(P=0.02)$, concentration of rumen total volatile fatty acid tended to be higher $(P=0.05)$ and acetate was higher $(P=0.04)$ for $\mathrm{CHM}$-diet than for $\mathrm{MH}$-diet. Turnover rates of plasma glucose and leucine did not differ between diets. Oxidation rate of leucine tended to be higher $(P=0.06)$ for $\mathrm{CHM}$-diet than for MH-diet, but the WBPS did not differ between diets. Metabolic heat production tended to be greater $(P=0.05)$ for $\mathrm{CHM}$-diet than for $\mathrm{MH}$-diet.

Conclusions: The sheep fed on CHM-diet had a higher body weight gain and showed positive impacts on rumen fermentation and energy metabolism without resulting in any adverse response. Therefore, these results suggested that the Chinese herbal medicine mixture should be considered as a potential feed additive for sheep.

Keywords: Chinese herbal medicine, Glucose metabolism, Heat production, Protein metabolism, Ruminal fermentation characteristics, Sheep

\section{Background}

Antibiotics have been widely used as feed additive in livestock production for more than $50 \mathrm{yr}$ [1]. They have played a very important role in helping animals to prevent diseases and enhance productivity. However, their use in animal diets has also brought along the hidden danger of drug residues to human health [2]. At present, the use of antibiotic growth promoters in animal industry is restricted in the European Union. It is likely that the restrictions on the use of antibiotics in animal husbandry will spread to the rest of the world due to the increasing public concern on human health. Therefore,

\footnotetext{
* Correspondence: sano@iwate-u.ac.jp

Faculty of Agriculture, Iwate University, 3-18-8 Ueda, Morioka 020-8550, Iwate, Japan
}

(C) 2013 Liang et al.; licensee BioMed Central Ltd. This is an Open Access article distributed under the terms of the Creative Commons Attribution License (http://creativecommons.org/licenses/by/2.0), which permits unrestricted use, distribution, and reproduction in any medium, provided the original work is properly cited. The Creative Commons Public Domain Dedication waiver (http://creativecommons.org/publicdomain/zero/1.0/) applies to the data made available in this article, unless otherwise stated.

replacing antibiotics with alternative feed additives has become the specific research interest to animal scientists.

Chinese herbs as the traditional medicine have been widely used in East Asian countries. For thousands of years, they have made great contributions to the maintenance of human health. Most of the Chinese herbal medicine comes from the different parts of perennial herbs, such as the leaves, roots and stems. It has been well-known that Chinese herbal medicine contains the bioactive components which have anti-bacterial activity, anti-inflammatory properties and immune enhancing effects [3]. Because of the natural origin, Chinese herbal medicine will not cause excessive drug residue or toxicity and thus it can be considered as a safe and 
suitable substitute for antibiotics in animal feeding. In recent years, a lot of Chinese herbal medicine has already been reported to promote growth and boost immune system in pigs, chickens and other animals [4-6].

It was considered that such numerous Chinese herbal medicine provide a great potential for practical application and some of them could be used as alternative feed additive for ruminants. Until now, little information is available regarding the performance of Chinese herbal medicine on nutrients and energy metabolism in ruminants. We hypothesized that Chinese herbal medicine might be beneficial to nutrients and energy metabolism in ruminants due to its bioactive properties. Therefore, the present study was carried out to assess the effects of feeding a traditional nourishing Chinese herbal medicine mixture on kinetics of plasma glucose, protein and energy metabolism in sheep.

\section{Methods}

Animals, diets and management

The handling of animals, including cannulation and blood collection, was reviewed and approved by the Animal Care Committee of Iwate University. All experimental procedures were performed without any noticeable stress to the animals.

According to the classical Chinese pharmacopoeia, a traditional nourishing Chinese herbal medicine mixture was utilized in this study. Three herbs were mixed in proportion as 55\% of Astragalus root (Astragalus membranaceus), 27\% of Angelica root (Angelica sinensis) and 18\% of Atractylodes rhizome (Atractylodes lancea). The herbs are known to be rich in polysaccharides (Astragalus root) and essential oils (Angelica root and Atractylodes rhizome). In humans, the Chinese herbal medicine mixture is commonly used as a health regulator to remove tiredness and comfort stress by inducing hematopoiesis.

Four crossbred (Corriedale $\times$ Suffolk) shorn wethers, aged $7 \mathrm{mo}$ on average, weighing $29 \pm 2 \mathrm{~kg}$, were used in the experiment. The sheep were assigned to two dietary treatments, including either mixed hay ( $\mathrm{MH}$-diet) of orchardgrass (Dactylis glomerata) and reed canarygrass (Phalaris arundinacea) offered at maintenance level [7] or $\mathrm{MH}$-diet supplemented with $2 \%$ of Chinese herbal medicine mixture (CHM-diet). The chemical compositions of mixed hay and Chinese herbal medicine on air dry matter basis are shown in Table 1 . The sheep received mixed hay at $67 \mathrm{~g} / \mathrm{kgBW}^{0.75} / \mathrm{d}$ for both dietary treatments. The experiment was performed using a crossover design over two 35-day periods. The sheep were housed in individual pens in an animal room during the first four weeks of the experiment for adaptation. Then animals were moved to metabolic cages in a controlled environment house at an air temperature of $23 \pm 1^{\circ} \mathrm{C}$, with lighting present from 08:00 h to 22:00 h. Two sheep were fed on the MH-diet
Table 1 Chemical composition of experimental diets

\begin{tabular}{lcc}
\hline Items $^{*}$ & MH & CHM \\
\hline Dry matter, \% & 88.3 & 91.2 \\
CP, \% & 11.9 & 10.8 \\
$\mathrm{NDF}, \%$ & 65.1 & 47.2 \\
$\mathrm{ME}, \mathrm{kcal} / \mathrm{g}$ & 1.79 & $\mathrm{~N} / \mathrm{A}$ \\
\hline
\end{tabular}

*Values are presented on air dry matter basis.

$\mathrm{MH}=$ mixed hay of orchardgrass and reed canarygrass; $\mathrm{CHM}=$ Chinese herbal medicine mixture; $\mathrm{CP}=$ crude protein; $\mathrm{NDF}=$ neutral detergent fiber;

$\mathrm{ME}=$ metabolizable energy; $\mathrm{N} / \mathrm{A}=$ not available.

during the first period and then fed on the CHM-diet during the second period. The other two sheep were subjected to the dietary treatments in the reverse order. The animals were given either diet twice a day at 08:30 $\mathrm{h}$ and 20:30 h, and they commonly consumed all the diets which were fed within $1 \mathrm{~h}$. Water was available ad libitum. The sheep were weighted at the start of experiment, on day 15 and 29, and at the end of each dietary treatment.

\section{Experimental procedures}

On day 33 of each dietary treatment, rumen fluid $(30 \mathrm{ml})$ was collected through a stomach tube before feeding, 3 and $6 \mathrm{~h}$ after feeding. After determination of $\mathrm{pH}$ values of rumen fluid with a $\mathrm{pH}$ meter (HM-20E, Toa Electronics Ltd., Japan), the rumen fluid was centrifuged at $8,000 \times g$ for $10 \mathrm{~min}$ at $4^{\circ} \mathrm{C}$ (RS-18IV, Tomy, Japan). Then $1 \mathrm{ml}$ of supernatant was mixed with $1 \mathrm{ml}$ of $0.1 \mathrm{~N} \mathrm{HCl}$. The prepared samples and the residuals of rumen fluid were stored at $-30^{\circ} \mathrm{C}$ for the determinations of rumen ammonia $\left(\mathrm{NH}_{3}\right)$ and volatile fatty acid (VFA), respectively.

Two sheep were subjected to the experimental procedures to determine plasma glucose, protein and energy metabolism on day 34 and 35, respectively. The other two sheep were determined in the reverse order. The turnover rate of plasma glucose was measured with an isotope dilution method using $\left[\mathrm{U}_{-}{ }^{13} \mathrm{C}\right]$ glucose. The rates of plasma leucine turnover and leucine oxidation, whole body protein synthesis and metabolic heat production were measured using the $\left[1-{ }^{13} \mathrm{C}\right]$ leucine dilution and open circuit calorimetry. Two catheters, one for isotope infusion and the other for blood collection were inserted into the left and right jugular veins on the morning of day 34 of each dietary treatment. The catheters were filled with sterile solution of $3.8 \%$ trisodium citrate.

At $12: 00 \mathrm{~h}$ on the day of $\left[\mathrm{U}^{-13} \mathrm{C}\right]$ glucose dilution, $3.0 \mu \mathrm{mol} / \mathrm{kgBW}^{0.75}$ of $\left[\mathrm{U}_{-}{ }^{13} \mathrm{C}\right]$ glucose (D-glucose- ${ }^{13} \mathrm{C}, 99$ atom\% excess ${ }^{13} \mathrm{C}$; Cambridge Isotope Laboratories, USA) dissolved in saline solution ( $0.9 \%$ sodium chloride) was injected into the jugular catheter for infusion as a priming dose. After the priming injection, $\left[\mathrm{U}^{13} \mathrm{C}\right]$ glucose was then continuously infused by multichannel peristaltic pumps (AC-2120, Atto, Japan) at rate of $3.0 \mu \mathrm{mol} / \mathrm{kg}^{0.75} / \mathrm{h}$ 
through the same catheters for $4 \mathrm{~h}$. Blood samples were taken from the sampling catheter immediately before $(12 \mathrm{ml})$ and at 30-min intervals $(6 \mathrm{ml})$ during the last $120 \mathrm{~min}$ of isotope infusion. The collected samples were immediately transferred into centrifuge tubes containing heparin sodium and were stored in crushed ice. Plasma was separated from blood samples by means of centrifugation at $10,000 \times g$ for $10 \mathrm{~min}$ at $4^{\circ} \mathrm{C}$ and then stored at $-30^{\circ} \mathrm{C}$ for further analysis.

At $11: 30 \mathrm{~h}$ on the day of $\left[1-{ }^{13} \mathrm{C}\right]$ leucine dilution, the sheep were fitted with a clear head chamber (approximately $0.2 \mathrm{~m}^{3}$ ) to collect the samples of exhaled gas. After collecting gaseous samples in the pre-infusion period, $7.2 \mu \mathrm{mol} / \mathrm{kgBW}^{0.75}$ of $\left[1-{ }^{13} \mathrm{C}\right]$ leucine (L-leucine- $1-{ }^{13} \mathrm{C}, 99$ atom\% excess ${ }^{13} \mathrm{C}$; Cambridge Isotope Laboratories, USA) and $3.5 \mu \mathrm{mol} / \mathrm{kgBW}^{0.75}$ of $\mathrm{NaH}^{13} \mathrm{CO}_{3}$ (sodium bicarbonate- ${ }^{13} \mathrm{C}$, 99.2 atom\% excess ${ }^{13} \mathrm{C}$; Cambridge Isotope Laboratories, USA) dissolved in saline solution were injected into the infusion catheter as a priming dose. Then, $\left[1-{ }^{13} \mathrm{C}\right]$ leucine was continuously infused by multichannel peristaltic pumps at rates of $7.2 \mu \mathrm{mol} /$ $\mathrm{kg}^{0.75} / \mathrm{h}$ through the same catheters for $6 \mathrm{~h}$. Blood samples were taken from the sampling catheter immediately before $(12 \mathrm{ml})$ and at 30 -min intervals $(6 \mathrm{ml})$ during the last $120 \mathrm{~min}$ of isotope infusion. The catheters were removed at the end of isotope infusions on day 35 of each dietary treatment.

Oxygen $\left(\mathrm{O}_{2}\right)$ consumption and carbon dioxide $\left(\mathrm{CO}_{2}\right)$ production were monitored continuously for $30 \mathrm{~min}$ at the end of $\left[1-{ }^{13} \mathrm{C}\right]$ leucine infusion using a metabolic monitor (Coast Electronics, UK). An aliquot of exhaled $\mathrm{CO}_{2}$ was collected in $4 \mathrm{ml}$ of $1 \mathrm{~N} \mathrm{NaOH}$ for $30 \mathrm{~min}$ immediately before and three times during the last $90 \mathrm{~min}$ of $\left[1-{ }^{13} \mathrm{C}\right]$ leucine infusion to measure the enrichment of exhaled $\mathrm{CO}_{2}$ derived from leucine oxidation. The $\mathrm{CO}_{2}$ samples were stored at $-30^{\circ} \mathrm{C}$ for further analysis.

\section{Chemical analysis}

Analysis of chemical components of the diets was performed according to Association of Official Analytical Chemists [8]. Nitrogen contents in diets were analyzed using the Foss Kjeltec System (Kjeltec 2300, Foss, Sweden). The NDF contents in diets were measured according to Van Soest et al. [9] using the Foss Analytical FiberCap ${ }^{\text {тм }}$ system (Foss, Sweden).

Concentrations of rumen $\mathrm{NH}_{3}$ were determined with a colorimetric method [10] using a spectrophotometer (V-630, JASCO, Japan). Concentrations of rumen VFA were measured using a gas chromatography (HP-5890, Hewlett Packard, USA) after steam distillation.

Concentrations of plasma free amino acids and urea were determined using an automatic amino acid analyzer (JLC-500/V, JEOL, Japan). Concentrations of plasma non-esterified fatty acid (NEFA) were enzymatically determined using a diagnostic kit (NEFA C, Wako Pure Chemicals, Japan).

Plasma glucose was derivatized to glucose aldonitrile pentaacetate according to the procedure of Tesrng and Kalhan [11] with slight modifications by Fujita et al. [12]. Enrichments of plasma [U- $\left.{ }^{13} \mathrm{C}\right]$ glucose were measured by gas chromatography mass spectrometry (QP-2010, Shimadzu, Japan). Concentrations of plasma glucose were enzymatically determined with a glucose oxidase method of Huggett and Nixon [13].

Concentrations of plasma $\alpha$-ketoisocaproic acid ( $\alpha$-KIC) and enrichments of plasma $\alpha-\left[1-{ }^{13} \mathrm{C}\right] \mathrm{KIC}$ were measured by gas chromatography mass spectrometry according to the procedures of Rocchiccioli et al. [14] and Calder and Smith [15]. The exhaled $\mathrm{CO}_{2}$ captured in $1 \mathrm{~N} \mathrm{NaOH}$ solutions was released by adding $6 \mathrm{~N} \mathrm{H}_{2} \mathrm{SO}_{4}$ into the samples in rubber capped vials under a vacuum condition, and the isotopic abundance of exhaled ${ }^{13} \mathrm{CO}_{2}$ was determined using a gas chromatography-combustion-isotope ratio mass spectrometric system $\left(\right.$ DELTA $^{\text {plus }}$, Thermo Electron, USA).

\section{Calculations}

The turnover rates of plasma glucose and leucine (GluTR and LeuTR, respectively) as well as leucine oxidation rate (LeuOX) were calculated using the equations given by Wolfe [16]:

$$
\mathrm{TR}=I \times(1 / E-1)
$$

Where, $I$ represents the infusion rates of $\left[\mathrm{U}-{ }^{13} \mathrm{C}\right] \mathrm{glu}-$ cose and $\left[1-{ }^{13} \mathrm{C}\right]$ leucine, and $E$ represents the plasma isotopic enrichments of $\left[\mathrm{U}_{-}{ }^{13} \mathrm{C}\right]$ glucose and $\alpha-\left[1-{ }^{13} \mathrm{C}\right]$ $\mathrm{KIC}$ during the steady state, respectively. In the present study, the enrichment of plasma $\alpha-\left[1-{ }^{13} \mathrm{C}\right] \mathrm{KIC}$ was used to calculate LeuTR instead of plasma $\left[1-{ }^{13} \mathrm{C}\right]$ leucine, because it is a more useful indicator to determine leucine metabolism [17].

$$
\text { LeuOX }=E_{C O 2} / E_{K I C} / 0.81 \times V_{C O 2}
$$

Where, $\mathrm{ECO}_{2}$ is the isotopic enrichment of exhaled ${ }^{13} \mathrm{CO}_{2}$ and $\mathrm{VCO}_{2}$ is the $\mathrm{CO}_{2}$ production rate. The recovery fraction of exhaled $\mathrm{CO}_{2}$ production in the animal body was estimated to be 0.81 [18]. Whole body protein synthesis (WBPS) was calculated using the following equation as described by Wolfe et al. [19]:

$$
\begin{aligned}
\mathrm{WBPS}= & (\text { LeuTR-LeuOX }) \\
& / \text { leucine concentration in carcass protein }
\end{aligned}
$$

Leucine concentration in carcass protein $(66 \mathrm{~g} / \mathrm{kg})$ was used as described by Harris et al. [20]. 
Heat production (HP) was calculated based on the Brouwer's equation [21] using $\mathrm{O}_{2}$ consumption and $\mathrm{CO}_{2}$ production as described by Young et al. [22]:

$$
\mathrm{HP}=3.866 \times V_{\mathrm{O} 2}+1.2 \times V_{\mathrm{CO} 2}
$$

Where, $\mathrm{Vo}_{2}$ is the $\mathrm{O}_{2}$ consumption rate and $\mathrm{Vco}_{2}$ is the $\mathrm{CO}_{2}$ production rate.

\section{Statistical analysis}

Statistical analysis was conducted according to the MIXED procedure of SAS [23]. The analysis of variance was used to test the effects of period and diet, and sheep were the random effect. Results were considered significant at $P<0.05$ level, and tendency was at $0.05 \leq P<0.10$.

\section{Results}

Mean values with standard error of the mean (SEM) were given. Body weight gain of sheep and the ruminal fermentation parameters are shown in Table 2. The sheep fed on CHM-diet had a greater $(P=0.03)$ daily weight gain than those fed on $\mathrm{MH}$-diet. Rumen $\mathrm{pH}$ was lower $(P=0.02)$ for CHM-diet than for MH-diet. Concentration of rumen $\mathrm{NH}_{3}$ remained similar between diets. Concentration of rumen total VFA tended to be higher $(P=0.05)$ and acetate was higher $(P=0.04)$ for $\mathrm{CHM}$-diet than for MH-diet.

Plasma free amino acids, urea and NEFA determined in the pre-infusion period of isotope dilution method are presented in Table 3. Concentration of plasma aspartic acid was higher $(P=0.02)$ and those of threonine, leucine, phenylalanine, alanine, proline and total amino acid tended to be higher $(P<0.10)$ for $\mathrm{CHM}$-diet than

Table 2 Effects of Chinese herbal medicine on body weight gain and ruminal fermentation characteristics in sheep

\begin{tabular}{lcccc}
\hline Items & MH-diet & CHM-diet & SEM & $P$-value \\
\hline BW gain, g/day & 16 & 25 & 6 & 0.03 \\
$\mathrm{pH}$ & 6.99 & 6.84 & 0.04 & 0.02 \\
$\mathrm{NH}_{3}, \mathrm{mmol} / \mathrm{L}$ & 10.7 & 11.2 & 0.6 & 0.65 \\
Total VFA, mmol/L & 86.2 & 92.8 & 3.2 & 0.05 \\
Acetate, $\mathrm{mmol} / \mathrm{L}$ & 60.5 & 64.5 & 2.1 & 0.04 \\
Propionate, $\mathrm{mmol} / \mathrm{L}$ & 17.2 & 19.1 & 0.9 & 0.35 \\
Iso-butyrate, mmol/L & 0.6 & 0.7 & 0.01 & 0.15 \\
Butyrate, $\mathrm{mmol} / \mathrm{L}$ & 6.5 & 7.2 & 0.3 & 0.34 \\
Iso-valerate, $\mathrm{mmol} / \mathrm{L}$ & 0.8 & 0.9 & 0.02 & 0.21 \\
Valerate, $\mathrm{mmol} / \mathrm{L}$ & 0.5 & 0.5 & 0.01 & 0.12 \\
\hline
\end{tabular}

$\mathrm{MH}$-diet $=$ mixed hay of orchardgrass and reed canarygrass; $\mathrm{CHM}$-diet $=\mathrm{MH}$-diet supplemented with $2 \%$ of Chinese herbal medicine mixture; SEM = standard error of the mean; $\mathrm{BW}=$ body weight; VFA = volatile fatty acids.
Table 3 Effects of Chinese herbal medicine on concentrations of plasma metabolites at pre-infusion period in sheep

\begin{tabular}{lcccc}
\hline Items & MH-diet & CHM-diet & SEM & P-value \\
\hline Essential amino acids, & Mmol/L & & & \\
Threonine & 258 & 282 & 20 & 0.07 \\
Valine & 268 & 315 & 17 & 0.13 \\
Methionine & 25 & 27 & 2 & 0.52 \\
Iso-leucine & 89 & 109 & 7 & 0.21 \\
Leucine & 129 & 156 & 9 & 0.09 \\
Phenylalanine & 61 & 68 & 4 & 0.06 \\
Histidine & 58 & 64 & 3 & 0.44 \\
Lysine & 112 & 130 & 9 & 0.16
\end{tabular}

Non essential amino acids, $\mu \mathrm{mol} / \mathrm{L}$

$\begin{array}{lcccc}\text { Aspartic acid } & 7.2 & 8.1 & 1.1 & 0.02 \\ \text { Serine } & 141 & 159 & 6 & 0.30 \\ \text { Asparagine } & 52 & 60 & 3 & 0.24 \\ \text { Glutamic acid } & 78 & 90 & 4 & 0.15 \\ \text { Glutamine } & 311 & 349 & 17 & 0.32 \\ \text { Glycine } & 467 & 501 & 25 & 0.39 \\ \text { Alanine } & 190 & 207 & 9 & 0.08 \\ \text { Tyrosine } & 90 & 95 & 7 & 0.37 \\ \text { Tryptophan } & 32 & 47 & 4 & 0.34 \\ \text { Arginine } & 141 & 149 & 11 & 0.19 \\ \text { Proline } & 107 & 124 & 8 & 0.09 \\ \text { Total amino acid } & 2616 & 2940 & 268 & 0.07 \\ \text { Urea, mmol/L } & 6.5 & 7.2 & 0.8 & 0.10 \\ \text { NEFA, mEq/L } & 0.16 & 0.14 & 0.03 & 0.12\end{array}$

$\mathrm{MH}$-diet $=$ mixed hay of orchardgrass and reed canarygrass; $\mathrm{CHM}$-diet $=\mathrm{MH}$-diet supplemented with $2 \%$ of Chinese herbal medicine mixture; SEM = standard error of the mean; NEFA = non-esterified fatty acid.

for $\mathrm{MH}$-diet. Concentrations of plasma urea and NEFA did not differ between diets.

Concentration of plasma glucose and enrichment of plasma $\left[\mathrm{U}-{ }^{13} \mathrm{C}\right]$ glucose remained constant during the last $2 \mathrm{~h}$ of isotope infusion for each dietary treatment (Figure 1). Concentration of plasma glucose and GluTR did not differ between diets (Table 4).

Concentration of plasma $\alpha$-KIC and enrichments of plasma $\alpha-\left[1-{ }^{13} \mathrm{C}\right] \mathrm{KIC}$ and exhaled ${ }^{13} \mathrm{CO}_{2}$ were stable during the latter period of $\left[1-{ }^{13} \mathrm{C}\right]$ leucine infusion (Figure 2). Concentration of plasma $\alpha$-KIC remained similar for both dietary treatments. Plasma LeuTR did not differ between diets. The LeuOX tended to be greater $(P=0.06)$ for CHM-diet than for MH-diet, but the WBPS did not differ between diets. Metabolic heat production tended to be greater $(P=0.05)$ for CHM-diet than for $\mathrm{MH}$-diet (Table 4). 


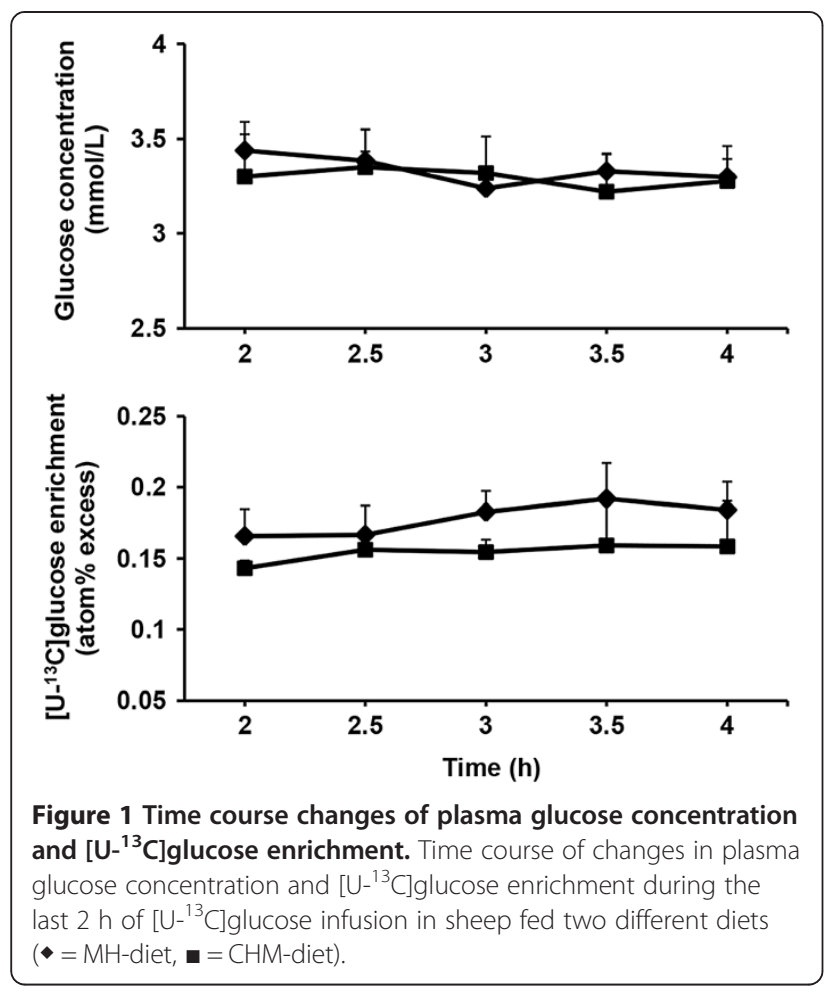

\section{Discussion}

\section{Ruminal fermentation characteristics}

In ruminants, the rumen is a large fermentation chamber which plays a very important role in feed digestion. The VFA is produced as the digestive product of dietary carbohydrates through microbial fermentation in the rumen. In the present study, concentration of rumen total VFA tended to be higher and acetate was higher in sheep fed on CHM-diet than on MH-diet. These results indicated that ruminal fermentation conditions might be improved and the fermentation of dietary carbohydrates was modified by Chinese herbal medicine. Angelica root and Atractylodes rhizome contain considerable amounts

Table 4 Effects of Chinese herbal medicine on plasma glucose, protein and energy metabolism in sheep

\begin{tabular}{lrrrr}
\hline Items & MH-diet & CHM-diet & SEM & P-value \\
\hline Glucose concentration, mmol/L & 3.36 & 3.33 & 0.15 & 0.84 \\
GluTR, mmol/ $\mathrm{kg}^{0.75} / \mathrm{h}$ & 1.45 & 1.56 & 0.04 & 0.17 \\
a-KIC concentration, $\mathrm{mmol} / \mathrm{L}$ & 9.5 & 8.9 & 1.3 & 0.42 \\
LeuTR, $\mu \mathrm{mol} / \mathrm{kg}^{0.75} / \mathrm{h}$ & 398 & 422 & 23 & 0.16 \\
LeuOX, $\mu \mathrm{mol} / \mathrm{kg}^{0.75} / \mathrm{h}$ & 102 & 160 & 11 & 0.06 \\
WBPS, g/ $/ \mathrm{kgBW}^{0.75} / \mathrm{d}$ & 14.1 & 12.5 & 1.4 & 0.15 \\
HP, $\mathrm{kcal} / \mathrm{kg}^{0.75} / \mathrm{h}$ & 3.94 & 4.25 & 0.07 & 0.05 \\
\hline
\end{tabular}

$\mathrm{MH}$-diet $=$ mixed hay of orchardgrass and reed canarygrass; $\mathrm{CHM}$-diet $=\mathrm{MH}$-diet supplemented with $2 \%$ of Chinese herbal medicine mixture; SEM = standard error of the mean; GluTR = turnover rate of plasma glucose; $\mathrm{a}-\mathrm{KIC}=\mathrm{a}$-ketoisocaproic acid; LeuTR = turnover rate of plasma leucine; LeuOX = oxidation rate of leucine; WBPS $=$ whole body protein synthesis; $\mathrm{HP}=$ heat production . of essential oils which have been well recognized as the main bioactive components of the two herbs $[24,25]$. Both in vitro and in vivo studies have shown that essential oils could favorably manipulate rumen fermentation by changing VFA production. Castillejos et al. [26,27] reported that essential oils could increase total VFA production and acetate proportion in continuous culture fermenters. The feeding effects of essential oils in growing lambs were studied by Chaves et al. [28], who observed the significantly higher concentration of rumen total VFA in the experimental groups than in the control group. Similar results can also be found in dairy cows [29]. These research findings may clarify the observation of our current experiment, where the changes in rumen VFA concentration might be largely due to the effect of essential oils in CHM-diet.

The $\mathrm{NH}_{3}$ is produced as the product of dietary nitrogenous substances through microbial fermentation in the rumen. In the present study, rumen $\mathrm{NH}_{3}$ concentration remained similar between diets. Castillejos et al. [30] reported that essential oils had no influence on $\mathrm{NH}_{3}$ concentration of rumen fluid in a long term in vitro incubations. Similar response on rumen $\mathrm{NH}_{3}$ concentration was also observed in cows by Yang et al. [31]. In addition, various reports have verified that rumen $\mathrm{NH}_{3}$ concentration was influenced by dietary $\mathrm{CP}$ intake [32,33]. Because the addition of Chinese herbal medicine was small (only $2 \%$ ) in our current experiment, the lack of change in rumen $\mathrm{NH}_{3}$ concentration might also be partly related to a comparable $\mathrm{CP}$ intake between dietary treatments.

Rumen $\mathrm{pH}$ values were within the normal range for both dietary treatments. The lower rumen $\mathrm{pH}$ for CHMdiet might be associated with the higher rumen VFA concentration, which agrees with Salman et al. [34] who demonstrated that rumen $\mathrm{pH}$ values were contrary to total VFA concentration in goats.

\section{Plasma NEFA and free amino acids}

Plasma NEFA is an important indicator of nutritional status in farm animals, which can directly indicate the adverse responses to such as fasting, negative energy balance or stress [35-37]. In our present study, concentration of plasma NEFA did not differ between diets and the values were presented within normal range for sheep. It indicated that the sheep fed on CHM-diet had comparable nutritional status with those fed on $\mathrm{MH}$-diet without causing any adverse response or stress.

El-Shafei et al. [38] supplemented Astragalus root to broiler chick diets, and reported that the total protein in serum significantly increased probably due to a hormonal regulating effect of Astragalus root on protein metabolism. In association with the current experiment, although the level of total protein in blood was not 

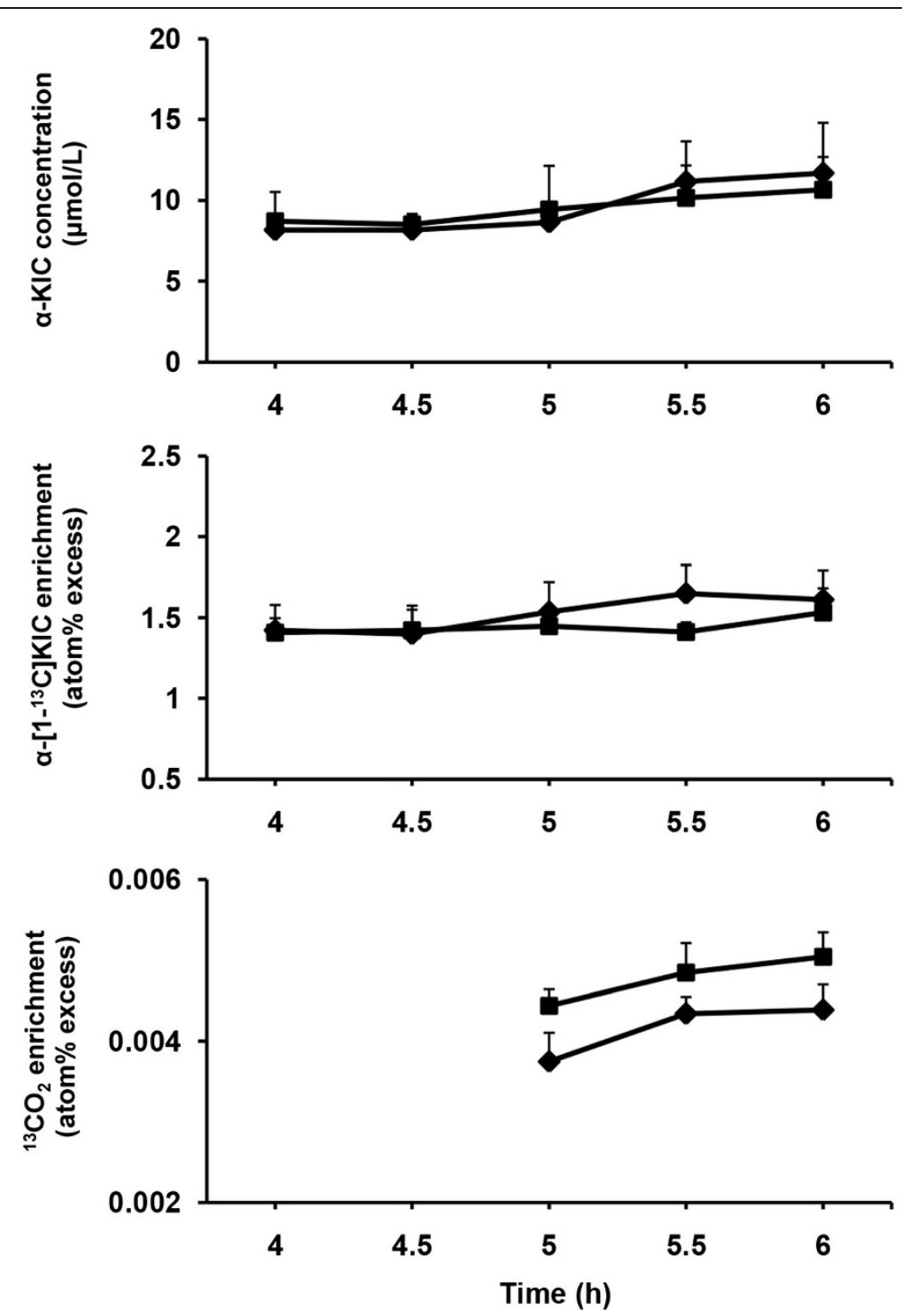

Figure 2 Time course changes of plasma a-KIC concentration and enrichments of plasma $\mathbf{a}-\left[1-{ }^{13} \mathrm{C}\right] \mathrm{KIC}$ and exhaled ${ }^{13} \mathrm{CO}_{2}$. Time course of changes in plasma a-ketoisocaproic acid (a-KIC) concentration and enrichments of plasma $\mathrm{a}-\left[1-{ }^{13} \mathrm{C}\right] \mathrm{KIC}$ and exhaled ${ }^{13} \mathrm{CO}_{2}$ during the latter period of $\left[1{ }^{13} \mathrm{C}\right]$ leucine infusion in sheep fed two different diets $(\bullet=\mathrm{MH}$-diet, $\mathbf{m}=\mathrm{CHM}$-diet).

determined, the trend of higher concentrations of certain plasma amino acids and total amino acid might be related to the bioactivity of herbs in CHM-diet.

\section{Plasma glucose and protein kinetics}

Based on the knowledge from human research, it has been well-known that the Chinese herbal medicine mixture is able to induce hematopoiesis by accelerating the generation, growth and maturity of blood cells [39]. Although it was expected that plasma glucose metabolism would be enhanced by the Chinese herbal medicine in sheep due to its bioactive properties on hematopoiesis, no positive impact was found on either plasma glucose concentration or plasma GluTR in the current experiment. In ruminants, because the dietary carbohydrates are fermented to VFA by microbes in the rumen, most of the glucose must be supplied through gluconeogenesis. Therefore, the supply of glucose precursor is considered as the major factor to influence glucose metabolism [40]. In our present study, propionate, the major glucogenic substrate produced in the rumen, did not differ between diets. It indicated that glucose precursors from the rumen were similar and thus the gluconeogenesis might be comparable between dietary treatments. Al-Mamun et al. [41] reported that plasma glucose concentration and turnover rate did not differ in sheep fed on plantain herb (a perennial 
herb having anti-bacterial and anti-inflammatory properties) or mixed hay, which is in accordance with our present findings.

Plasma LeuTR and the WBPS did not differ between diets. Nevertheless, it was found that higher numerical values of plasma LeuTR resulted in lower numerical values of the WBPS for CHM-diet than for $\mathrm{MH}$-diet. This may be largely due to the calculation method as we used plasma LeuTR and LeuOX to calculate the WBPS, where the differences in LeuOX were greater than those in LeuTR. Similar data can also be found in a previous report of Sano et al. [42]. So far, little information is available regarding the performance of Chinese herbal medicine on plasma amino acid kinetics and protein synthesis in ruminants. The data obtained from human research is also limited. Al-Mamun et al. [43] reported that plasma LeuTR decreased but the WBPS remained unchanged in sheep fed on plantain herb compared with fed on mixed hay, which partly agrees with our present findings. Li et al. [44] used $\left[{ }^{15} \mathrm{~N}\right]$ glycine as the tracer to determine the effect of a Chinese herbal medicine mixture (Astragalus root and Angelica root, same as the present study) on protein metabolism in nephrotic patients, and observed that Chinese herbal medicine could improve the disorder of protein metabolism and increase the level of serum protein by improving the net rate of protein synthesis. However, their findings are inconsistent with the results of our current experiment in sheep.

Taken together, the sheep fed on CHM-diet did not enhance plasma GluTR, LeuTR and WBPS as expected under the conditions of the present study. In the treatment of human diseases, Chinese herbal medicine is normally taken as syrup of its extract. The herbs are processed by boiling in order to remove foreign substances and reduce toxic contents as well as increase therapeutic effects [39]. During the feeding periods of our current experiment, the Chinese herbal medicine was directly given to the animals without any treatment, thus the lack of changes in GluTR, LeuTR and WBPS between dietary treatments might be partly related to the factor that we did not process the Chinese herbal medicine, so that it was not as effective as expected.

\section{Heat production}

Until now, to our knowledge, the effect of Chinese herbal medicine on heat production has not been investigated either in humans or in animals. Heat is defined as the released energy that is produced from the oxidation process of the nutritive substances such as carbohydrate, protein and fat in the body. In our present study, metabolic heat production tended to be greater for $\mathrm{CHM}$-diet than for $\mathrm{MH}$-diet. The trend of increased heat production indicated that Chinese herbal medicine might play a role in accelerating nutrients oxidation in sheep. It is in good accordance with the result of LeuOX, which also tended to be greater for CHM-diet than for MH-diet. Furthermore, the sheep fed on CHMdiet had a higher body weight gain than those fed on $\mathrm{MH}$-diet. Because energy is essential to animals in almost all life activities including maintenance, growth and production, the trend of increased heat production also demonstrated that the CHM-diet could provide more available energy for growth than $\mathrm{MH}-$ diet in sheep.

\section{Conclusions}

Although no significant effect on plasma glucose and protein metabolism was found, the sheep fed on CHMdiet had a higher body weight gain and showed positive impacts on rumen fermentation and energy metabolism without resulting in any adverse response than those fed on MH-diet. Therefore, these results suggested that the Chinese herbal medicine mixture should be considered as a potential feed additive for sheep.

\section{Competing interests}

The authors declare that they have no competing interests.

\section{Authors' contributions}

$\mathrm{XL}$, as the lead author, was in charge of all research work, including designing the protocol, carrying out the experiment and writing the manuscript. KY, MK, XB and AP participated in the lab work to perform the chemical analysis of all samples, and provided kind suggestions for the manuscript. HS, as the supervisor to the lead author, was involved in the design and execution of the study, and approved the final manuscript. All authors read and approved the final manuscript.

\section{Acknowledgements}

The authors are grateful to Jianjun Liu, Harbin University of Commerce, China, for providing Chinese herbal medicine for the experiment.

Received: 25 October 2013 Accepted: 16 December 2013

Published: 18 December 2013

\section{References}

1. Dibner JJ, Richards JD: Antibiotics growth promoter in agriculture: history and mode of action. Poult Sci 2005, 84:634-643.

2. Barton MD: Antibiotic use in animal feed and its impact on human health. Nutri Res Rev 2000, 13:279-299.

3. Huang KC: The Pharmacology of Chinese Herbs. 2nd edition. Boca Raton: CRC Press; 1998

4. Kong X, Hu Y, Rui R, Wang D, Li X: Effects of Chinese herbal medicinal ingredients on peripheral lymphocyte proliferation and serum antibody titer after vaccination in chicken. Int Immunopharmacolo 2004, 4:975-982.

5. Lien TF, Horng YM, Wu CP: Feasibility of replacing antibiotic feed promoters with the Chinese traditional herbal medicine Bazhen in weaned piglets. Livest Prod Sci 2007, 107:97-102.

6. Wang J, Zhou H: Comparison of the effects of Chinese herbs, probiotics and prebiotics with those of antibiotics in diets on the performance of meat ducks. J Anim Feed Sci 2007, 16:96-103.

7. National Research Council (NRC): Nutrient requirement of sheep. 6th edition. Washington, DC: National Academy Press; 1985.

8. AOAC: Official Methods of Analysis. 16th edition. Arlington, VA: Association of Official Analytical Chemists; 1995

9. Van Soest PJ, Robertson JB, Lewis BA: Methods for dietary fiber, neutral detergent fiber and non-starch polysaccharides in relation to animal nutrition. J Dairy Sci 1991, 74:3583-3597. 
10. Weatherburn MW: Phenol-hypochlorite reaction for determination of ammonia. Anal Chem 1967, 39:971-974.

11. Tserng KY, Kalhan SC: Estimation of glucose carbon recycling and glucose turnover with [U- $\left.{ }^{13} \mathrm{C}\right]$ glucose. Am J Physiol 1983, 245:E476-E482.

12. Fujita T, Majima H, Itoh T, Sano H: Combined effect of salinomycin and feeding on whole body glucose kinetics in sheep fed a high-concentrate diet. Reprod Nutr Dev 2006, 46:503-514.

13. Huggett AG, Nixon DA: Enzymatic determination of blood glucose. Biochem J 1957, 66:12.

14. Rocchiccioli F, Leroux JP, Cartier P: Quantitation of 2-ketoacids in biological fluids by gas chromatography chemical ionization mass spectrometry of o-trimethylsilyl-quinoxalinol derivatives. Biomed Mass Spectrom 1981, 8:160-164.

15. Calder AG, Smith A: Stable isotope ratio analysis of leucine and ketoisocaproic acid in blood plasma by gas chromatography/mass spectrometry. Use of tertiary butyldimenthylsilyl derivatives. Rapid Commun Mass Spectrom 1988, 2:14-16.

16. Wolfe RR: Tracers in metabolic research: radioisotope and stable isotope/mass spectrometry methods. New York: Alan R. Liss; 1984

17. Magni F, Arnoldi L, Galati G, Kienle MG: Simultaneous determination of plasma levels of a-ketoisocaproic acid and leucine and evaluation of $\mathrm{a}-\left[1-{ }^{13} \mathrm{C}\right]$ ketoisocaproic acid and $\left[1-{ }^{13} \mathrm{C}\right]$ leucine enrichment by gas chromatography-mass spectrometry. Anal Biochem 1994, 220:308-314.

18. Allsop JR, Wolfe RR, Burke JF: Tracer priming the bicarbonate pool. J Appl Physiol 1978, 45:137-139.

19. Wolfe RR, Goodenough RD, Wolfe MH, Royle GT, Nadel ER: Isotopic analysis of leucine and urea metabolism in exercising humans. J Appl Physiol 1982, 52:458-466.

20. Harris PM, Skene PA, Buchan V, Milne E, Calder AG, Anderson SE, Connell A, Lobley GE: Effect of food intake on hind-limb and whole-body protein metabolism in young growing sheep: chronic studies based on arterio-venous techniques. Brit J Nutr 1992, 68:389-407.

21. Brouwer E: In Energy Metabolism. Edited by Blaxter KL. London: Academic Press; 1965:302-304.

22. Young BA, Kerrigan B, Christopherson RJ: A versatile respiratory pattern analyzer for studies of energy metabolism of livestock. Can J Anim SCi 1975, 55:17-22.

23. SAS (Statistical Analysis System): SAS/STAT Software: Changes and enhancements through release. Version 6-11. Cary, NC: SAS Institute; 1996.

24. Wu MJ, Sun XJ, Dai YH, Guo FQ, Huang LF, Liang YZ: Determination of constituents of essential oil from Angelica sinensis by gas chromatography-mass spectrometry. I Cent South Univ 2005, 12:430-436.

25. Zhou J, Fang L, Wang X, Zhang J, Guo LP, Huang LQ: Comparison of the volatile compounds of crude and processed Atractylodis rhizome analyzed by GC-MS. Afr J Pharm Pharmacol 2012, 6:2155-2160.

26. Castillejos L, Calsamiglia S, Ferret A, Losa R: Effects of a specific blend of essential oil compounds and the type of diet of on rumen microbial fermentation and nutrient flow from continuous culture systems. Anim Feed Sci Tech 2005, 119:29-41.

27. Castillejos L, Calsamiglia S, Ferret A, Losa R: Effects of dose and adaptation time of a specific blend of essential oil compounds on rumen fermentation. Anim Feed Sci Tech 2007, 132:186-201.

28. Chaves AV, Stanford K, Gibson LL, McAllister TA, Benchaar C: Effects of carvacrol and cinnamaldehyde on intake, rumen fermentation, growth performance, and carcass characteristics of growing lambs. Anim Feed Sci Tech 2008, 145:396-408.

29. Soltan MAE, Shewita RS, AI-Sultan SI: Influence of essential oils supplementation on digestion, rumen fermentation, rumen microbial populations and productive performance of dairy cows. Asian J Anim SC 2009, 3:1-12.

30. Castillejos L, Calsamiglia S, Ferret A: Effect of essential oil active compounds on rumen microbial fermentation and nutrient flow in in vitro systems. J Dairy Sci 2006, 89:2649-2658.

31. Yang WZ, Benchaar C, Ametaj BN, Chaves AV, He ML, McAllister TA: Effects of garlic and juniper berry essential oils on ruminal fermentation and on the site and extent of digestion in lactating cows. J Dairy Sci 2007, 90:5671-5681.

32. Freeman AS, Galyean ML, Caton JS: Effects of supplemental protein percentage and feeding level on intake, ruminal fermentation, and digesta passage in beef steers fed prairie hay. J Anim Sci 1992, 70:1562-1572
33. Alam MK, Ogata Y, Sako Y, Al-Mamun M, Sano H: Intermediary metabolism of plasma acetic acid, glucose and protein in sheep fed a rice straw-based diet. Asian-Aust J Anim Sci 2010, 23:1333-1339.

34. Salman FM, El-Kadi RI, Abdel-Rahman H, Ahmed SM, Mohammad MI Shoukry MM: Biologically treated sugar beet pulp as a supplement in goat rations. Int J Agric Biol 2008, 10:412-416.

35. Sticker LS, Thompson DLJ, Bunting LD, Fernandez JM, DePew CL: Dietary protein and (or) energy restriction in mares: plasma glucose, insulin, nonesterified fatty acid, and urea nitrogen responses to feeding, glucose, and epinephrine. J Anim Sci 1995, 73:136-144.

36. Chelikani PK, Ambrose JD, Keisler DH, Kennelly JJ: Effect of short-term fasting on plasma concentrations of leptin and other hormones and metabolites in dairy cattle. Domest Anim Endocrin 2004, 26:33-48.

37. Hristov S, Maksimovic N, Stankovic B, Zujovic M, Pantelic V, Stanisic N, Zlatanovic Z: The most significant stressors in intensive sheep production. Biotechnology in Animal Husbandry 2012, 28:649-658.

38. El-Shafei AA, Al-Gamal MA, Abdelrahman AS, Arafa MM: Influence of different levels of Astragalus root powder in broiler chick diets on the physiological and biochemical changes. J Appl Sci Res 2013, 9:2104-2118.

39. Li X, Wei W: Chinese Materia Medica: Combinations and Applications. Potters Bar: Donica Publishing; 2002.

40. Ortigues-Marty I, Vernet J, Majdoub L: Whole body glucose turnover in growing and non-productive adult ruminants: meta-analysis and review. Reprod Nutr Dev 2003, 43:371-383.

41. Al-Mamun M, Tanaka C, Hanai Y, Tamura Y, Sano H: Effects of plantain (Plantago lanceolata $\mathrm{L}$.) herb and heat exposure on plasma glucose metabolism in sheep. Asian-Aust J Anim Sci 2007, 20:894-899.

42. Sano H, Kajita M, Fujita T: Effect of dietary protein intake on plasma leucine flux, protein synthesis, and degradation in sheep. Comp Biochem Physiol 2004, 139:163-168.

43. Al-Mamun M, Hanai Y, Tanaka C, Tamura Y, Sano H: Responses of whole body protein synthesis and degradation to plantain herb in sheep exposed to heat. Arch Anim Nutr 2008, 62:219-229.

44. Li L, Yu H, Pan J: A study on protein metabolism in nephrotic patients treated with Chinese herbs. Zhonghua Nei Ke Za Zhi 1995, 34:670-672.

doi:10.1186/2049-1891-4-51

Cite this article as: Liang et al.: Effects of Chinese herbal medicine on plasma glucose, protein and energy metabolism in sheep. Journal of Animal Science and Biotechnology 2013 4:51.

\section{Submit your next manuscript to BioMed Central and take full advantage of:}

- Convenient online submission

- Thorough peer review

- No space constraints or color figure charges

- Immediate publication on acceptance

- Inclusion in PubMed, CAS, Scopus and Google Scholar

- Research which is freely available for redistribution 